\title{
The Role of Arts in Promoting Tourism: A Case of tourism Development in Thamel Area
}

\author{
Chiranjivi Bhatta
}

Senior Artist
cm@hotelartskathmandu.com

\begin{abstract}
Thamel is a touristic area in Kathmandu which has become the main attraction for tourists for the last more than three decades. It is popularly known as the heart of tourists industry in Kathmandu. It was developed along with the arrival of hippies, many of them were artists too. Before that, the tourist attraction was concentrated in Jhonchen area. Hippies came to Nepal in search of enlightenment and spent weeks in Thamel. Along with the tourism promotion through arts and culture, there are lots of challenges in promoting arts and tourism in Thamel which needs special attention from the government of Nepal. It is crucial to recognize the important role that arts play in the positive and healthy tourism development of any society. Government needs to have strategies for partnership between arts, tourism and economic development because it is the key to foster a strong tourism destination. The union of arts and tourism celebrates human authenticity, and increases opportunities for self improvement and creates more genuine experiences along with the employment opportunities directly and indirectly.
\end{abstract}

\section{KEY WORDS: Thamel, Arts, Tourist, Tourism, Culture}

\section{INTRODUCTION}

An area of tourism that is often overlooked is the question of the arts and tourism. One of the reasons for this consistent overlooking may be the fact that it is hard to define the term "the arts". In popular parlance the term usually means what is technically called the "plastic arts". That is those forms of the arts that are restricted to paintings, sculpture and other visual concepts. Of course, the term can mean much more, from musical and dance performances to theater, from architecture to poetry readings all are art forms. In fact, anywhere that we find that the embodiment of the soul in a communication with other souls we find art. As such we may also think of both athletics and religious expression as a form of art (Tarlow, 2011).

In creative placemaking, partners from public, private, nonprofit and community sectors strategically shape the physical and social character of a neighborhood, town, city or region around arts and cultural activities (Watson, 2013).

There are hardly few tourists who visit to Nepal miss to explore Thamel, the popular destination nowadays. Tourists can find best restaurants, handicrafts, clothing shops and best bookshops, best spas here. Tourists relax and have fun in this place where they get to meet all kind 
of pleasures and entertainment. Most of the tourist who come to visit Nepal for leisure purpose prefer to stay in Thamel area as it is the most convenient and fun place to explore the city. Tourists can find everything they need -trekking equipments and rentals as well, bicycle on rents, arrangement for treks, rafting, wildlife tours and sightseeing tour. Wide range of mountaineering gear shops, foreign money exchange booths, pubs, clubs and nightlife along with the travel agents, guest house and hotels are available in Thamel. Another popular attraction in Thamel is handicraft shops. Several handicraft shops are available in Thamel which offers variety of hand - knotted woolen carpets, pashmina shawls, jewelry, woolen knitwear, embroidery, thagnka paintings, wood carvings, statues and decorative metallic house wares, ceramics and pottery and rice paper products such as writing pads, calendars and lamp shades. These are the popular things tourist often buy to take back home. Another thing that attracts tourist in Thamel is arts that are beautifully captured in the canvas. Arts and painting can be found in every streets of Thamel. There are more than 50 art galleries in Thamel that displays various arts and painting. These art galleries contain different types of paintings. Some paintings are found to be the beautiful landscape of Nepal and some are the outcome of creative and beautiful imaginations of artists. This leads to an attraction of numerous tourists having diverse interest in various types of art and paintings. These kinds of travelers also help to encourage the artists that are trying to do something new and superfluous. Nepal art is unique, exotic and enchanting. Nepalese expressions of art, classical and modern style are embedded in the daily practice of religion. Craftsmanship is the most easily found in temple, architectures, shrines, fountains, and the designs of religious objectives.

The key is to treat the arts as an essential part of the city's identity. Successful creative place making builds the economy at the local level, enhances surrounding non-arts businesses and provides job opportunities and ways for individuals to participate in activities associated with the arts and cultural events. The results bring people together, spark community pride and create a more vibrant "place" (Watson, 2013).

\section{ARTS}

There are many forms of art through which artist can express their creative skills and imaginations in various forms. Major forms of arts that are popular in Nepal are as follows:

\section{Thangka}

One of the main types of art is also known as thangka which is popularly known worldwide. Thangka is more predominant form of paintings which is more popular among Buddhists in Nepal. These paintings on cotton are rectangular in shape and are usually longer than they are wide. They are framed with three stripes of Chinese brocade of blue, yellow and red which represent the rainbow that separates sacred objects from the material world. Older thangkas consisted of mineral based colors while current thangkas are produced with vegetable based or chemical colors. Frequent themes of thangkas include image of Buddhist figures, mandala designs, the wheel of life design, or depiction of scenes or stories (Kreijger, 1999). 


\section{Architectures}

The real architectures of Nepal are found in the temples, stupas and other religious building and monuments. Usually there are three types of Temples in Nepal which are pagoda, shikaras and stupas. Shikaras might be Hindu or Buddhist Temple but Stupas are completely a Buddhist Temple. Most of the Buddhist temples are surrounded by a wall with a defined entrance way. The Stupa is surrounded by wall of prayer wheels and the prayers make a round touching those prayer wheels.

\section{Pottery}

Pottery is one of the oldest forms of arts which are flourished in Patan and Bhaktapur, historical places of Newar community in Nepal. Many forms of pottery can be found among which terra cotta oil lamps used to light homes during the festival Dipawali, and flower pots decorated with peacocks and elephants are very common (Amatya, 2003).

\section{Bronze Figures}

Bronze figures are also one of the oldest form in Nepal which is seen in the valley around $8^{\text {th }}$ Century AD. Bronze figures are sometimes alloyed with the copper. Usually bronze figures are made as religious deities or legendary people. Images made from bronze often contain embedded semi precious stones, coral or turquoise or are sometimes glided with gold.

\section{HISTORY OF TOURISM}

Ancient tourism was mainly based on cultural purpose. Manjushree was the first person to come Nepal who cut chovar hill and let all the water go outside making the Kathmandu valley livable. Chinese, Tibetans and Indians used to visit Nepal for religious and commercial purpose. After unification of Nepal by King Prithvi Narayan Shah, Captain Kirkpatric, a military official came to collect facts about Nepal. He wrote a book "An account of the kingdom of Nepal" which helped to introduce Nepal to outsiders (Young, 2015).

No foreigners were allowed to visit Nepal until 1951 under the autocratic Rana Regime from the time they took over the country. One of the first foreigners to visit Nepal was Sir Edmund Hillary, the first person to climb the Mount Everest successfully on May 29, 1953. In 1955, Nepal issued its first tourist visa on request by Mr. Boris Lissanevitch. Mr. Boris is the legendary Russian hotelier. The first tourists to come through were 10 Americans and 2 Brazilians. They stayed at the famous Royal Hotel, the first tourist standard hotel which was started by Boris himself. Initially the majority of the tourists were Americans who were of the retirement age.

During the late 1960s the hippie trail started to take off. Hippies are the group of young people who followed liberal anti war philosophy. Nepal was the prime destination of hippies as buying and selling of hashish was legal till 1979. Their objective was to discover their inner-self and for this reason they wanted to stay away from their home as long as possible. This played very important role in advertising and promoting Nepal as tourism attraction. Hippies who came to Nepal became kind of good ambassador of Nepal as they keep on telling cultural and natural 
beauties of Nepal on way back their home. With the establishment of the Drug Enforcement Administration in 1973, hashish transaction was considered illegal due to which the hippie trail came to an end in 1979.

During 1975-1991, Nepal was the hot spot for holiday makers, adventures seekers and cultural tourists. Lot of tourists start visiting Nepal and the number of the tourist increased from 100,000 to 300,000 in a year. In 1998 Nepal celebrated "Visit Nepal 98" to strengthen Nepal tourism.

Though tourism has a long history in Nepal, it has really developed after 1950s which has now emerged as a major contribute to the country's economy. With the world's largest mountain range and many areas of untouched nature, Nepal attracts many tourists, trekkers and climbers and has become one of the hottest destinations for tourism.

Tourism fostered later in Thamel. Before tourism hit Thamel, numbers of tourists were to be found in small streets located at the south of Kathmandu Durbar Square which is presently known as old freak street. This ancient street was named as Freak Street referring to the Hippies trail of the 1960s and the 1970s. During that period of that time, the main attraction drawing tourists to Freak Street was the government run Hashish shops legally. Later, the flow of tourists got shifted towards Thamel as the transaction of Hashish became illegal and the hippie tourism was quickly replaced with the more conventional businesses of trekking and tourism. Kathmandu Guest House was the most popular guest house in Thamel area which is also one of the main reason tourist started knowing this place as they started in that guest house. Slowly, numbers of tourist accommodations and attractions were developed in Thamel which boosted the Thamel tourism. Different hotels and restaurants started to operate in Thamel that served as a tourist standard hotel.

\section{TOURISM AND ARTS}

The concept of art tourism sounds new but it is definitely as old as tourism itself because for centuries, many societies had already given much appreciation for the arts and culture. Art tourism covers a big segment of the industry because around the globe people travel in order to visit, explore and engage in activities related to art festivals, concerts, and wine and cuisine events and to explore famous museums.

Art tourism can be defined as a partnership between culture and the tourism industry by creatively increasing what is unique about a community. The heritage, artistic and cultural life of an area can attract tourists and create better quality of life for those who live there. For example The Americans for the Arts Monographs mentioned "In 1992 the Arts Council of New Orleans and the New Orleans Tourism Marketing Corporation began an initiative to build a partnership between these two industries". This statement presents that it is important to understand the crucial role that the arts play in the beautification and attractiveness of a destination. Another example states "The Minister of Tourism Malaysia, announced the 1st. Malaysia Contemporary Art Tourist 2010 aims at targeting more high-yield tourists." (Tourism Malaysia Media Release 2010). As declared in this media release, tourism leaders and governments need to work in collaboration in 
order to develop and deliver imaginative experiences and driven authentic products to increase new visitors.

Arts and culture are a potent force in the life of towns and cities making them more attractive which increases the chances for more visitors. As declared in the An Art \& Cultural Tourism Strategy for Western Australia (2008), “The western Australian Government recognizes the dynamic interaction between the arts and the tourism market and has made a coordinated approach to marketing Western Australian arts and culture a priority". As proclaimed in this tourism strategy, culture and the arts are a key element in the positive development of a tourist destination. A city or town with diverse cultural options and attractions like museums, restaurants, art galleries, operas, theaters, and symphonies are attractive not only to their residents, but for visitors because tourists can discover more and have memorable experiences.

Art tourism is more expensive than other types of tourism which creates differences between people. No doubt that the nature of art tourism and the art industry is more reachable for the art connoisseurs and enthusiasts. Because of this valid argumentation it is essential for governments and tourism organizations to develop strategies for culture and the arts to be available to all demographics. For instance more governments and tourism leaders are gearing modernization and service improvements towards the promotion of their native arts to gain a holistic edge in the travel industry.

Cultural tourism is one of the largest and fastest-growing global tourism markets. The Impact of Culture on Tourism examines the growing relationship between tourism and culture, and the way in which they have together become major drivers of destination attractiveness and competitiveness (OECD, 2009).

\section{METHODOLOGY}

Questionnaire was prepared according to which local people were interviewed and beside that observation was made. The methodology was carried out in Thamel. For the analysis of the study, available books, reports and digital media have been consulted.

\section{RESULTS}

In Thamel, tourism is one of the major economic sources of foreign currency as the number of tourist from different parts of world come to visit our country and spend their currency while staying in Nepal. Tourism is not only important sources of foreign currency but also a major employment generator. It creates employment opportunities to a large number of manpower including both skilled and non skilled manpower. By the medium of tourism people, can exchange knowledge and create understanding among the people of the world. Tourism provides us an opportunity to understand society, habits, food and the way of life style of different nations. Directly and indirectly people in Nepal are getting benefits from the tourism. Many people are getting employment from this sector and because of the demands of local products, incentives to the local crafts and industries and artistic skills of the people have been increased. Traditional 
ceremonies, art and industry are reviewed because tourists are interested in them. Socially and culturally, tourism encourages intellectual curiosity among people and nations and develops a healthy respect for another's beliefs and customs.

Numbers of tourist travelling worldwide has their own specific interest. People usually travelling to Nepal are found to be interested in the diversity of arts and culture that are found in here. The real architecture of Nepal is found in the Nepal Temples, stupas and other religious buildings and monuments. There are various local destinations that reflect the history and cultures of our country through different art and architecture. However in Thamel, all this kinds of histories and cultures are captured in the frames of canvas and paintings that can be found within Thamel that are exhibited in more than 50 art galleries. People who have keen interest in arts and paintings can most likely are to be found in Thamel area. These kinds of tourists encourage the artists by appreciating their work which will eventually help to preserve our history and culture though art.

\section{Number of international tourists arriving in Nepal:}

\begin{tabular}{|l|l|}
\hline Year & Number of internationals tourists arriving in Nepal \\
\hline 2010 & 602,855 \\
\hline 2011 & 736,215 \\
\hline 2012 & 803,092 \\
\hline 2013 & 798,000 \\
\hline 2014 & 790,118 \\
\hline 2015 & 554,747 \\
\hline
\end{tabular}

Source: Ramsharan Thapaliya, President, Thamel Tourism Council

\section{WORDS FROM TOURISTS}

While carrying out this study, I interviewed several tourists from many countries. Their responses were as follows:

1. Mr. Simmons from Florida, USA - "This area is front and centre for the foreigner visitor. You can find anything you want here from dinner to travel agencies to help you plan the rest of your time in Nepal. The people are helpful, friendly and informative. The best place to start and end your trip to Nepal. "

2. Mr. Prabhat from India- "It's a great place. Always packed with tourists. Nice pubs, live music, places, sheesha bars, tons of cafes and eateries. Good to see free Wi-Fi almost every place. The saying "shop till you drop" always holds good here."

3. Mr. Shoeb from New York -“lots of stores, with handicrafts, great bargain, good 
restaurants, coffee shops, and nice place to tour by walking."

4. Ms. Reena Mohan from Dubai - "Thamel is a place not to be missed if you are shopaholic... Right form gorgeous artifacts to funky handbags and shoed to great finger food... it's all there! True spirit of Nepal can be captured here."

5. Yingkoi from Thailand - "Thamel is one of the best shopping area for arts, antiques, clothing and equipments for trekkers. Easy to find difference kinds of restaurant, budget hotels. It's the place that makes you enjoy every day.

\section{CHALLENGES}

One of the main challenges for Nepal to promote arts and tourism is the political instability. People will not visit any country that is not politically instable as they will not have proper security in that country. Internal war or any kind of conflict can start any time which is why there will be no any proper security. There are still many places in Nepal which do not have infrastructures like no transportation facility, no electricity. There is shortage of necessary infrastructures for proper development of existing as well as feasible tourists place. Basic requirements needs for the development of tourism are still in adequate. For example, there is a very beautiful place in Nepal named Rara Lake but there is no proper transportation facility from Kathmandu or any other cities to Rara Lake. So many people might not know about that place or people who know also cannot go to that place easily. Therefore, government should look after these things so that more people can reach to these kinds of beautiful places in Nepal. It is also found that government is not organizing any programs for the marketing and promotions of neither Nepal nor any investments are being done for the betterment of art and tourism in Nepal. Nepal Tourism Board organizes and participates in the marketing programs in other countries yearly spending millions of money but government does not even make attempt to make roads to beautiful places in rural areas. Limited marketing budget for the development of tourism is seen. World heritage sites are properly maintained in case of cultural tourism. Problem of overcrowding and environment pollution is increasing which is hampering the tourism in Nepal. Thamel is the main hub for tourist. Most of the tourists who come to visit Nepal for leisure purpose prefer to stay at Thamel area but because of the sound pollution it is hard for them to stay in hotels located at Thamel area. There are many clubs and discos in Thamel which makes noises during night which disturbs the guest staying in that area. But government has not made any rules which can minimize and solve these kinds of problems. It is found that there is lack of attention paid by government to maintain standard in tourism industry in Nepal.

In order to attract tourist, government should have preserve existing culture, arts and movements and research in this filed should be carried out to introduce new culture and best arts. Another problems usually tourist face in Nepal is the sanitation and hygiene problem. There for 
government should take major steps to overcome these problems. Organizing programs and setting the rules to keep the city clean, arranging public toilet, these are the kinds of things that need to be done by government to make the city clean. To increase the foreign currency and number of tourist arrivals, concerned authority must give attention to lengthen their stay and provide good security for tourist. Develop tourism, tourist information centers should be established in different parts of Nepal so that tourists could easily get information about hotel. Traveling routes trekking etc. to develop tourism in Nepal, political should be stable, concerned authority must implement tourism awareness, proper education and new tourism policies.

\section{CONCLUSION:}

Nepal is natural and scenic beauty and has been successful in presenting herself the wonderful in the world. It is because of this, tourism and its development has been a subject of major concern. It is considered to be one of the powerful developing aspects for our country. And the artists have captured those beauties in their paintings which are another way of attracting tourists who are more interested in arts. Tourists can find paintings of natural beauties and imaginations in every street of Thamel which is the heart of tourism industry in Nepal. But there are challenges in promoting art and tourism for which government has to develop plans and also it can coordinate with local government municipalities, NGOs/INGOs and private sectors in Nepal.

\section{Bibliography}

Amatya, G. (2003). Modern Art.

Kreijger, H. E. (1999). Kathmandu Valley Painting .

OECD. (2009, January ). The Impact of Culture on Tourism.

Tarlow, P. (2011, October). The Arts and Tourism . Tourism and More.

Watson, C. (2013, May). How the arts and culture tourism spur economic development. The Monthly Magazine of the Leage of California Cities. Retrieved from http://www.cacities.org/

Young, S. M. (2015). The Rough Guide to Nepal. 